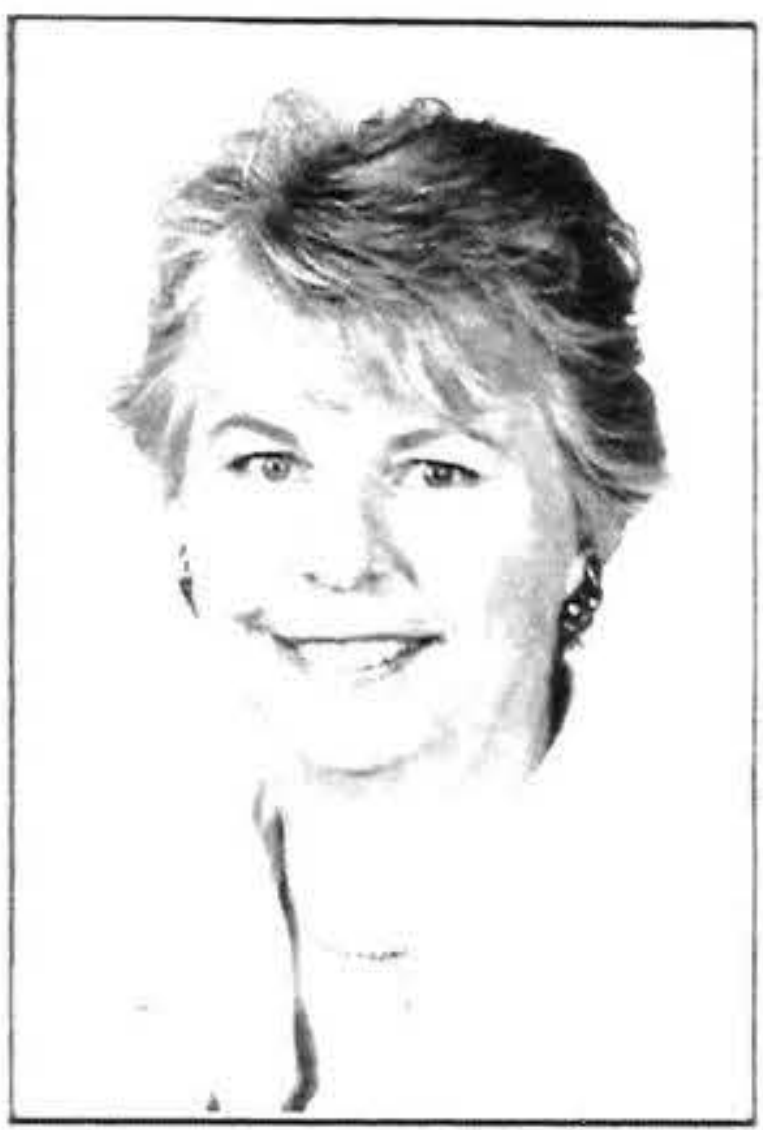

\title{
FEMALE UNION DELEGATES: THE CLASS STRUGGLE AND SEXUAL EQUALITY
}

\author{
Rae Nicholl \\ Victoria University of Wellington
}

\begin{abstract}
Compulsory unionism in New Zealand in the past meant that women had to sign up and join their local trade union branch - but there was no compulsion to become actively involved. Yet many women did permit themselves to be nominated and became union delegates. They persisted too, even though much of the literature tells us that male unionists were either indifferent or hostile to female involvement in the trade union movement. In the strictly male hierarchical trade union movement, women had little chance, until very recently, of gaining representation at influential levels. Despite this, many women stuck with their principles and represented their co-workers. Why did they do it? Was it because the class war was more important to them than the sex war? Did they try to fight both oppressions simultaneously? Did they believe overcoming one - the battle against the employers - would help alleviate male oppression generally? Or did they not find the attitudes of some male unionists a problem at all? Five older trade union women were interviewed on audio tape for this research topic and were asked to discuss their experiences with male trade unionists and, specifically to talk about their attitudes towards feminism and the feminist movement. The international work published by Alice Cook on the experiences of women as both members and office-holders in trade unions forms the empirical base of the paper.
\end{abstract}

The legal compulsion on New Zealand workers to join a trade union proved so successful that, by 1991,48 percent of the female workforce was unionised. ${ }^{1}$ But whilst women were legally bound to belong to a union, there was no similar compulsion for them to become actively involved. Yet many women did permit themselves to be nominated and became union delegates. They persisted, too, even though much of the literature tells us that male unionists were either indifferent or hostile to female involvement in the trade union movement.

The research project, upon which this paper is based, involved an analysis of women's historical place within the trade union movement. This was complemented by a dialogue with five older activist women concerning particular aspects of unionism and feminism. It is my intention now to present three inter-related aspects of that research. Firstly I outline the project upon which this paper is based, discuss the ethical issues involved and introduce three of the women who participated. Secondly, I explain - very briefly - the theoretical skeleton upon which I imposed the experiences of my interviewees and, finally, I discuss their views of feminism and male/female - and female/female - relationships within trade unionism.

\section{Interviews}

In the strictly male hierarchical trade union movement, women had little chance, until very recently, of gaining representation at influential levels. Despite this, many women, motivated by a desire to achieve social justice for the less privileged members of society, represented their co-workers who were, in the main, other women. My paper is based on audio-taped interviews with five older trade union women. All the women were caucasian. During the conversations, I asked them why they had become union delegates. I was interested to know if they found male trade unionists helpful, difficult or obstructive? Where they had encountered sexism, did they still believe that fighting the class war was more important than tackling sexism within their own unions? Did they think they could attack both oppressions simultaneously? Or did they believe that by overcoming one - the battle against the employers - male oppression generally would be alleviated? I also asked them, specifically, about their attitudes towards feminism and the feminist movement and how their feminism had correlated with their trade union involvement, if this had been the case. What I found, in fact, was that, in the main, the women were more interested in exploring their relationships with other women within the union movement. This did not mean that they had not acknowledged and confronted sexism - they had - but in the course of conversation it became apparent that their involvement with other women was of greater interest, and pertinence, to them.

Interviewing people involves trust. The interviewees must feel confident that the interviewer will betray no confi- 
dences if they are to respond spontaneously and generously to the interviewer. The interviewer, for her part, needs to be sensitive to the feelings and concerns of the interviewees who have, often at some inconvenience to themselves, agreed to be interviewed. Mutual feelings of trust are especially important when dealing with sensitive or controversial events that interviewees may have experienced in their lives. There are two approaches to this problem. Firstly, it is essential to formalise this trust by both parties agreeing on a carefully considered Code of Ethics and, secondly, it is incumbent on the interviewer to adopt ethical interviewing techniques. Three of the women I interviewed gave me complete clearance to use their material as I wished, but the remaining two imposed certain restrictions. As a consequence, you will not be hearing the voices of those two women, but their insights are included in the collective experience.

The first woman I interviewed was Sylvia Kelly, nee Pocock. She was born in Killinchy in mid-Canterbury in 1929 and died in Porirua in 1993. With nine children to care for, the need to supplement 'poor men's wages' drove Sylvia Kelly to become a night cleaner in the early 1960 s. She began as a part-timer, joining the legions of women from Porirua who caught the 2.15 a.m. train into Wellington and returned on the $6.18 \mathrm{am}$. train, getting home in time to cook their children's breakfasts and to see their husbands off to work. Later in the $1960 \mathrm{~s}$, she became a full-time night supervisor before moving to a job at an old person's home in Titahi Bay, north of Wellington, in the 1970 s.

From the start, Sylvia Kelly was a very active unionist. In the late 1970 s, she was elected president of the Wellington section of the Hotel and Hospital Workers' Union and held this position for nearly ten years. At its peak, in the early 1980 s, the Wellington section had a membership of 12,000 members. ${ }^{2}$ Sylvia Kelly is credited with revitalising the union. Simultaneously, she spent some time as National Vice-President of the union, which had a total membership of 40,000 workers. $^{3}$ She was also active in the Labour Party for many years.

Betty Weeber, nee Gibson, my second interviewee, has impressive working class credentials. Both her parents were staunch unionists in England in the early part of the century. In 1930, when Betty Weeber was five, the family migrated to New Zealand, where her parents carried on their union and Labour Party activities, her father, John Gibson, eventually becoming National President of the New Zealand Engineers' Union and her mother, Lucy Gibson, nee Scarrott, founding and administering the Laundry Workers' Union. World War II proved a breaking point in the family's political life when both Betty Weeber's mother and brother espoused their pacificism. Her mother was forced from the Labour Party and also lost her job as secretary of the Laundry Workers' Union, while her brother was interned as a conscientious objector for four years during the war. Betty Weeber subsequently rejoined and was an active supporter of the Labour Party but her aversion to the 1984 Fourth Labour Government's New Right economic policies caused her to leave the
Party, her allegiances shifting to New Labour when Jim Anderton founded the Party in 1989.

When Betty Weeber's five children were young, economic necessity caused her to seek part-time employment and she became a Home Help in 1972, employed by Wellington Hospital. This job entailed travelling to the homes of people who were unable, through sickness or disability, to maintain a minimum level of cleanliness for themselves. The work was often dirty, heavy and stressful. Home Helps were not unionised and, following in her mother's footsteps, Betty Weeber determined to form a union. The task was not simple and took seven years, but the Home Helps eventually were accepted as a unit within the Hotel and Hospital Workers' Union in 1984.

Karen Butterworth nee Peterson was the third activist I interviewed. She was born in 1934 in the Caitlins district of South Otago. At the age of nine, she contracted polio and was paralysed for three months but was able to make an almost complete recovery. After a chequered early career which included journalism and teaching, and with a young child to support, she embarked on a long-standing and successful career in the public service. During her years of mainly full-time employment, she belonged to the Public Service Association. She invested enormous energy in union work, often finding herself in conflict with her superior officers because of her commitment. Her efforts were principally directed towards the establishment of permanent part-time career positions in the public service and towards the provision of safe, affordable daycare for children.

\section{Women's experience in trade unions}

The second section of my paper introduces the international work of Alice Cook, in particular her 1984 collaborative work, Women and Trade Unions in Eleven Industrialised Countries. Cook's work presents the best overview I have found of women's experiences in trade unions in western countries (although New Zealand is not included). ${ }^{4}$ Cook believes that Western European trade unions have all passed through similar stages of development in their attitudes towards women workers. She has divided these into three phases: a period of anti-feminism; a period of protection of women; and a contemporary period, which involves trade unions adopting programmes designed to promote equality. ${ }^{5}$ By using these three divisions as a framework, it is possible to demonstrate that the same developmental sequence has occurred in New Zealand's trade unions as in other industrialised countries. Further, this framework allowed me to juxtapose the problems faced by activist women in the New Zealand trade union movement and, in this way, to illustrate a few of the problems they encountered with male unionists.

The first period Cook defines is one of anti-feminism. During this time men employed various techniques to exclude women from unions or, if they were permitted to join, to undermine the benefits of membership and to deny them a voice in union decision-making. This anti-feminism found its base in Britain in the belief (often well- 
founded) that women workers undercut the wages of men. A further rationale for their exclusion was the accusation that women were less militant and less willing to defend workers' rights than men were. ${ }^{6}$ In their desire to exclude women, male unionists sometimes colluded with employers. When Joan Shields researched New Zealand women meatworkers for a 1983 study, she found that a 'gentleman's agreement' existed between the union and the meat companies to restrict female employment. The same union official who passed on this information also believed that women in the meat works were 'more dangerous than the atomic bomb' and that 'women meat workers earn more in their lunch hour than they do on the job'?

The second period - the period of protection of women included practices such as restrictive legislation, the deskilling of women workers (men are skilled pressers, women do the ironing), the non-availability of apprenticeships to girls and women, job segregation - which includes the double load that women carry, and the problems associated with part-time work - as well as paternalism. Paternalism is generally taken to be the belief held by some male trade unionists that it is their right to represent women and to speak on their behalf. ${ }^{8}$ This paternalism can be observed in New Zealand in all the female-dominated unions that have been headed by men. Patricia Sarr reported that the New Zealand Caretakers and Cleaners' Union, (which amalgamated with the Hotel Workers' Union to form the Service Workers' Union), always had a female membership of over 80 percent but never had a paid woman as union secretary. 9

Cook's final stage in the development of male attitudes towards women in trade unionism is the contemporary period. By this stage, women had proved themselves to be effective unionists. Historically, a common union stereotype was that the presence of women in a union made it difficult to organise. However, a study undertaken in Australia by Anne Game and Rosemary Pringle found the opposite to be true. 10 Australian women expressed a keener sense of injustice than men and also had a greater willingness to pursue not only their own self-interest but the interests of workers as a whole. They proved to be amongst the most active and knowledgeable of shop stewards and, because of this knowledge, Game and Pringle believe unions worldwide should be encouraged to involve women in organising struggles to protect jobs, wages and working conditions because they are more likely to have a clearer and more integrated perspective on the kinds of changes that are needed.

Of my interviewees, Sylvia Kelly was the only women amongst the group of five to have headed a union when she was elected to the position of president of the Wellington division of the Hospital and Hotel Workers' Union in 1979.

I turned the union around...For years, it had been run by hotel working people because it was basically set up as a hotel workers' union... Then the hospital unions came into it... Because we had been run by hotel-working men for so long, I became the first woman who stood for the
Wellington executive. I got on it...They were running a complete new ticket because the old president was in his late seventies. He should have been retired. He was no longer working within the industry...We got the representatives from each award group in the union to stand on the new ticket - public hospital, rest homes, restaurants, tea rooms. They all got in and turned the union completely around.

Patricia Sarr's study of the contemporary period shows that by 1991 there were 11 women union presidents and 10 men. Arguably holding positions of greater influence and importance, eight women and 13 men had been appointed union secretaries. Of note is the fact that the eight women secretaries represented some 94,000 union members and the 13 men secretaries some $271,000.11$ In other words, there was one woman secretary per 11,750 members, while each male secretary represented 20,846 members. These figures were collated before the introduction of the Employment Contracts Act 1991, which abolished compulsory unionism and caused a massive loss in union membership. One of the results has been that several female-dominated unions amalgamated, for example the Hospital and Hotel Workers Union amalgamated with the Cleaners' Union to form the Service Workers Union.

Although these gains look impressive, Arlene Kaplan Daniels believes that western unions do not differ markedly from other institutions in society, so when only lip service or minor or token changes will serve, western unions are generally supportive of women. 12 However, when drastic, expensive changes are required to accommodate women's interests, western unions -all too often agree with employers that such aims are 'too visionary'. Daniels asserts that western unions have backed away from issues such as part-time work, child-care provisions, parental leave and vocational training. But in defence of New Zealand unionism, Angela Foulkes, who is deputy president of the New Zealand Council of Trade Unions, has argued that this is not the case in New Zealand and, furthermore, that the improvement in the position of women in unions in New Zealand has been 'dramatic and swift'. 13 Unfortunately, it can be argued that Foulkes's opinion has become academic because many of the advances made by women in the workforce have been undermined by legislation enacted by the 1990 National Government. The repeal of pay equity legislation, the cuts made to the entitlement to childcare subsidies for low income families, the continued lack of paid maternity leave for most families and the introduction in 1991 of the Employment Contracts Act are evidence of government policies that have adversely affected women workers.

\section{Unionists and feminism}

The third section of this paper concerns the opinions, beliefs and feelings the interviewees expressed regarding their attitude towards feminism. Feminism is sometimes seen as the preserve of white, middle class women with higher educational and professional occupations and is eschewed, as such, by working class women. ${ }^{14}$ Joyce Gelb has commented that British socialist-feminists have 
sought to forge links with trade unions in order to reach out to working-class women. 15 One of the reasons why this overture has not been taken up is that union women find, in particular, the separatist ideas of socialist-feminist women abhorrent. This feeling, coupled with the largely middleclass membership of the feminist movement, has made it difficult for the women's movement in Britain to make headway with its working-class contemporaries. This observation on the tension that can exist between middleclass and working-class women is applicable to some of the women I interviewed.

For Sylvia Kelly, the position of working-class women within the union movement had a profound effect on her attitude towards other female unionists. She found that the professional women, who were moving into the unions and taking over leadership roles in the late 1970s and early 1980 s, were not sympathetic to the needs of working-class women.

My horror experience - because I always look at it as a horror - was I found that the people who done the most damage to the working women's movement were the women themselves. I don't mean all working women. I mean the women who were professional, academic people who could afford the better type of life. Where I came from, and those people I represented, were the women who done early morning cleaning. The married women who went out to supplement poor men's wages.

When we went to the [Federation of Labour] conferences, hoping to talk about all the structures in working women's lives, because we were the bottom of the ladder...We weren't proficient enough to make our voices heard against the highly educated or the professional people, those people who intended to make their life a professional life. Women. And it was women. In our work life, we had men to fight because our service was Messenger and Cleaning, and because it was Messenger and Cleaning, the messengers were the top dogs and the cleaners were the little people that scurried around and cleaned up after everyone else.

When we went to the Women's Conference, it was the academic women and again we were relegated to the bottom of the rung. No-one was really very interested in the struggles we were having on our jobs.

Sylvia Kelly was deeply hurt by this experience and while she believed she could organise and outmanoeuvre male unionists - "We won that battle hands down. I became the new president." -she did not resolve her suspicion of 'academic' women whom, she believed, were not interested in the problems faced by uneducated women performing menial work.

While my interviewees were all white women, they were acutely concemed about other ethnic groups. Several of them commented about their efforts to involve Maori women in union activities. Sylvia Kelly reported that the
Federation of Labour assisted the Hospital and Hotel Worker's Union in setting up women's committees.

We had a women's committee and a Maori women's committee. They used to go on to different marae for their conferences...We did not segregate the conferences...The conferences were always both of us together but there might be a day set aside for the Maori women to present to us the support they wanted us to give them.'

Betty Weeber tried to encourage the Maori and Pacific Island women, who worked as Home Helps at Wellington Hospital, to take advantage of the same women's programme.

We also had seminars and they would be for two or three days... We had them on marae and that was an education in itself. Going to the marae, being welcomed on to the marae, learning about the marae. A lot of our union [Hotel and Hospital Workers] were either Maori or Pacific Islands. We discovered a lot of those women couldn't come to meetings and still can't because their husbands or their fathers or their brothers say they can't. Especially the Pacific Islanders are very much under the thumb of the male. We were trying to educate them and bring them out to get them involved in the union and explain why it was important to them.

The union-organised women's conferences, groupings and committees became an important source of information, education and inspiration for women unionists. Sylvia Kelly recounted how, from the 1970 s onwards, the Federation of Labour began organising a Women's Conference for women delegates, which was held one day before the full conference. While her experiences at full Federation of Labour Conferences had tended to be negative, with women delegates receiving little support from the men, and despite her reservations about the presence of professional women in the trade union movement, she found the Women's Conference to be far more successful and supportive.

With the enactment of the Employment Contracts Act 1991, the unions have had to contract as their membership has dropped. The women's groupings and committees came to an end. The Hospital and Hotel Workers' Union amalgamated with the Caretakers and Cleaners' Union to form the Service Workers' Union. Betty Weeber, whose Home Helps group had been a part of the Hospital and Hotel Workers' Union, was very unhappy with the outcome of the amalgamation.

Males from the Service Workers came in and the Maori, Pacific Islands and women's committees were disbanded. These males said, "Oh, we haven't got a male committee. We have all got to work together."

Towards the end of the interviews, each of the five women was asked if she considered herself a feminist. In com- 
ments that reflect their generation, two of the women mentioned the archetypical women's liberation activist of the 1970s - the bra-burning harridan. Sylvia Kelly's response also reflects, in some ways, not only long-held attitudes but also her experiences with middle-class women unionists, by whom she had been deeply offended.

No, I don't think I am a feminist. I still wear bras. No, definitely not. I do believe in some of the feminist movement but some of it I think is way out. I believe in women's rights...I don't believe women's rights is the sole platform for feminism. That's what my gut says. I think that the feminist movement is another movement that took over and done damage to some of their sisterhood because they have their strong ideals. They weren't prepared to listen or to share...It's a sisterhood of people, of women, together, of all creeds.

Betty Weeber positioned herself in the middle-ground and also did not see herself as a militant feminist.

Yes, I am, but not a bra-burning type. I believe we have to work together, male and female, but women have been downgraded and undergraded for centuries. That equality must come and we have got to fight for it. There have to be those people that are the fanatics, who really work hard for it, as well as the ones that travel the middle road.

Finally, Karen Butterworth was emphatic that she was a feminist, and that feminism had been a major part of her life for many years.

Yes. I was a feminist before the sixties wave. I read Bertrand Russell and Bernard Shaw in my teenage years, who shaped me a lot, and Simone de Beauvoir in my early twenties.

Of the five interviewees, three of the women could be described as spirited feminists. They had combined their union and feminist activities to gain concessions for all workers, yet they were concerned mainly with women, seeing them as the more oppressed group. The remaining two women were far more ambivalent about feminism, preferring instead to place their full energies in the union movement. However, since these women retired from the workforce, the political agenda for women has changed and it appears that feminism is retreating back into the middle classes and will become increasingly irrelevant to working-class women workers. Observations made by Mary Kenny, a British social commentator, are as applicable to New Zealand as they are to Britain. 16

Feminism today is much more about power, success, money, achievement than it is about theoretical notions of 'sisterhood', partly because sisterhood (like socialism itself) doesn't seem to work frightfully well. The 1960 ish notion that feminism was exclusively of the Left was not historically exact: feminism has been a coat of many colours and is generally cut out of the culture in which it is located... and is becoming free-market capitalist today.

Feminism may be entering a new phase in New Zealand also. Women claiming to be New Right feminists want to embrace capitalism whilst, at the same time, they continue to fight paternalism and patriarchy. Evidence for this can be found in the retention by the National Government of the Ministry of Women's Affairs, the continuation of Equal Employment Opportunity units within government departments and in the strengthening of legislation against pornography, sexual harassment and violence against women. The passing of the Employment Contracts Act in 1991 and the move towards a more market-oriented society has been applauded by some of these New Right feminists. For instance, New ZealandBusiness Roundtable employee Penelope Brook has been quoted as saying:

Rather than condemning the market, feminists ought to be glorying in it, for it has proved remarkably adaptable to women's evolving desire to work full-time, to work throughout their lives, and to work in new challenging jobs.... Why emphasise women's disadvantages? 17

But this is not the future my interviewees envisaged or desired. Karen Butterworth had spent her working life actively advancing a policy of permanent part-time work within the public service. With five children to care for, Betty Weeber never sought full-time employment. And had Sylvia Kelly's husband, with a family of nine children to support, received what she considered to be 'a family wage', she would not have become a night-cleaner. It is apparent that New Right policies offer few, if any, benefits to working-class women, both employed and unemployed. If New Right policies continue to be introduced which cut back on the benefits many working-class women receive from the state, many will find themselves in ever more tenuous positions. With union coverage no longer compulsory and unions themselves amalgamating, trade unions will find it increasingly difficult to protect women workers.

Finally, it is apparent that the interviewees endured the same problems and discriminations as many women unionists in other industrialised countries. Why then did these women stay? Principally, they stayed because they felt strongly about social justice, feelings which had sprung from experiences and influences in their childhoods. They all enjoyed their union involvement. Four of the women found the women's groupings within the union movement of enormous value and support to them personally. Within these groups, they forged connections and built relationships with other union women. They were inclusive and attempted to attract women from Maori and other ethnic groups into their orbit. Their commitment to social justice spilt over into other areas of their lives. Two of the women had been Communist Party members, one of whom later joined the Labour Party, and the other three have been Labour Party supporters, one of whom now belongs to the New Labour Party. In retirement, they had all continued 
to be involved in community projects of all dimensions. Many of the gains for which these five women fought have been lost and some were never realised. As I see it, they can reflect back now to an era that began to vanish when the National Government came to power in 1990.

\section{Future research}

Because so little has been collected, and written up, about the experiences of older trade unionist women, future research is vital. As it is, Sylvia Kelly remarked that 'a lot of the women who done early moming cleaning died very young.' This is borne out by the fact that I could not find one women trade unionist in Wellington aged over 70. Sylvia Kelly herself did not reach 70 . Any one of the areas of concern to women that has been covered so scantily in this paper could be researched in far greater depth. Of particular interest would be a study of how apprenticeship schemes were operated and their availability to young women, and an investigation into the patterns of leadership for women in both female and male dominated unions. A study of the attitudes of women trade unionists, to see how they have been influenced by the New Right philosophy of the Fourth Labour Government and the 1990 National Government, and by the values and beliefs of New Right feminists, would also be of value.

\section{Notes}

This paper is based on tape-recorded interviews made with Karen Butterworth, Sylvia Kelly, Betty Weeber and two other retired women trade unionists in the Wellington region during May 1993.

1 Patricia Sarr, Out of the Chorus Line: The Progress of Women in New Zealand Unions, New Zealand Council of Trade Unions, May 1992, p. 9.

2 Wellington Hotel and Hospital Workers' Union, Job Delegates Handbook, circa 1980, p. 1.

3 Job Delegates Handbook, p. 6.

4 Cook, Alice H., Val R. Lorwin and Arlene Kaplan Daniels, Women and Trade Unions in Eleven Industrialised Countries, Temple University Press, Philadelphia, 1984.

5 Alice Cook, quoted by Joni Lovenduski in Women and European Politics: Contemporary Feminism and Public Policy, Wheatsheaf Books, Brighton, 1986, p. 166.

${ }^{6}$ Lovenduski, Joni, Women and European Politics: Contemporary Feminism and Public Policy, Wheatsheaf Books, Brighton, 1986, p. 167.

7 Joan Shields, 'Women Meatworkers and the Gentleman's Agreement', in Women's Studies Journal, Vol. 2, No. 2, Auckland, August 1986, pp. 75-85.
8 Edna Ryan, 'Foreword', in Ann Game and Rosemary Pringle, Gender at Work, George Allen and Unwin, Sydney, 1983, p. 10.

${ }^{9}$ Sarr, Out of the Chorus Line, p. 16.

10 Anne Game and Rosemary Pringle, Gender at Work, George Allen and Unwin, Sydney, 1983, p. 40.

11 Sarr, Out of the Chorus Line, p. 16.

12 Arlene Kaplan Daniels, 'Conclusion', in Alice H. Cook, Val. R. Lorwin and Arlene Kaplan Daniels, eds., Women and Trade Unions in Eleven Industrialised

Countries, Temple University Press, Philadelphia, 1984,p. 314.

13 Angela Foulkes, Women in Unions, paper presented to the Women at Work: Issues for the 1990s Seminar, held at the Industrial Relations Centre, Victoria University of Wellington, 12 February 1993, p. 1.

${ }^{14}$ Elizabeth Wilson with Angela Weir, 'The British Women's Movement', in Elizabeth Wilson, Hidden Agendas Theory, Politics, Experience in the Women's Movement, Tavistock Publications, London, 1986, p. 103.

15 Joyce Gelb, Feminism and Politics: A Comparative Perspective, University of California Press, Berkeley,1989, p. 69.

16 Mary Kenny, 'Ladies of the Right', The Spectator, London, 3 July 1993, p. 9.

${ }^{17}$ Penelope Brook, as quoted by Suzanne Hammond and Raymond Harbridge in "The impact of the Employment Contracts Act on women at work'. Paper presented to the Women at Work: Issues for the 1990 s seminar held at the Industrial Relations Centre, Victoria University of Wellington, 12 February 1993.

\section{References}

Brook, P. 1993 Quoted in The impact of the Employment Contracts Act on women at work Hammond, S. and Harbridge, R: paper presented to the Women at Work: Issues for the 1990 s seminar held at the Industrial Relations Centre, Victoria University of Wellington, 12 February 1993.

Cook, A.H., Lorwin, V.R. and Daniels, A.K. 1984 Women and Trade Unions in Eleven Industrialised Countries Temple University Press, Philadelphia.

Daniels, A.K. 1984 Conclusion Women and Trade Unions in Eleven Industrialised Countries. In A.H. Cook, Lorwin V.R. and Daniels, A.K (eds) Temple University Press, Philadelphia: 314. 
Foulkes, A. 1993 Women in Unions, paper presented to the Women at Work: Issues for the 1990s seminar, held at the Industrial Relations Centre, Victoria University of Wellington, 12 February 1993.

Game, A. and Pringle, R. 1983 Gender at Work George Allen and Unwin, Sydney.

Gelb, J. 1989 Feminism and Politics: A Comparative Perspective University of California Press, Berkeley.

Kenny, M. 1993 Ladies of the Right The Spectator London Books, Brighton.

Ryan, E. 1983 Foreword Gender at Work A. Game and Pringle, R, George Allen and Unwin, Sydney: 10.

Sarr, P. 1992 Out of the Chorus Line: The Progress of Women in New Zealand Unions NewZealandCouncil of Trade Unions.

Shields, J. 1986 Women Meatworkers and the Gentleman's Agreement Women's Studies Journal, 2(2):75-85.

Wellington Hotel and Hospital Workers' Union c.1980 Job Delegates Handbook: 1.

Wilson, E. with Weir, A. 1986 The British Women's Movement. In Wilson, E. Hidden Agendas - Theory, Politics, Experience in the Women's Movement, Tavistock Publications, London: 103.

\section{Author}

Rae Nicholl is a PhD candidate in Politics, Victoria University of Wellington, PO Box 600 , Wellington. 